Момир Самарџић

Универзитет у Новом Саду

Филозофски факултет

Одсек за историју

samomomir@yahoo.com
Оригинални научни рад

примљено: 15. мај 2011

прихваћено: 1. октобар 2011

\title{
СУОЧАВАЊЕ СА МОДЕРНИЗАЦИЈСКИМ ИЗАЗОВОМ \\ - БРИТАНСКИ ИНФРАСТРУКТУРНИ ПРОЈЕКТИ НА БАЛКАНУ 1851 - 1852. И СРБИЈА
}

Сажетак: У јуну 1852. у Београду се појавила група британских инжењера која је претходно у Истанбулу преговарала о изградњи трансбалканске железнице, односно о повезивању османске престонице са аустријском границом на ушћу Саве у Дунав. Овај рад представља покушај контекстуализације поменуте идеје, полазећи од британских настојања да на најпогоднијим тачкама на Балканском полуострву створе нова трговачка упоришта у османским лукама и омогуће продор у унутрашњост изградњом неопходне саобраћајне инфраструктуре, укључујући железницу. Са друге стране, рад прати делатност српске владе у вези са овом идејом, полазећи од тренутног стања српске привреде, политичких сукоба у држави, те места Србије у односима великих сила.

Кључне речи: модернизација, саобраћајна инфраструктура, трансбалканска железница, Велика Британија, Србија, Османско царство, уставобранитељи, Источно питање, $1851-1852$.

У доба Индустријске револуције, од посебног значаја за привредни напредак сваке државе био је развој саобраћајне инфраструктуре. Све бржи индустријски развој западноевропских привреда, а пре свих британске и француске, наметао је питање изградње јединственог трансевропског транспортног система, односно укључење неразвијених и сировинама богатих области, у које је касније могуће извозити индустријске производе, као једно од најзначајнијих питања за развијене капиталистичке државе, усмеравајући улагања капитала, али и дипломатске напоре влада ка развоју саобраћајне инфраструктуре на европској географској и економској периферији као кораку ка изградњи јединствене европске транспортне мреже. ${ }^{1}$

\footnotetext{
${ }^{1}$ Ivan T. Berend, György Ránki, Evropska periferija i industrijalizacija 1780-1914, Zagreb 1996, 105-153.
} 
Као последица оваквог развоја, идеја о железничком повезивању истока и запада преко Османског царства појавила се у западној Европи готово у исто време када је почела градња првих железница, као новог, револуционарног средства масовног превоза. У Великој Британији се већ тридесетих година 19. века говорило о изградњи железнице преко османске територије. Основни разлог била је жеља за успостављање непосредне везе између метрополе и најважнијег колонијалног поседа - Индије. Током тридесетих, четрдесетих и педесетих година постојали су разни планови и трасе којим су британски предузетници намеравали уз помоћ владе да остваре овај задатак. ${ }^{2}$ Појава интересовања за краћу, медитеранску, руту према Индији, уместо до тада примарне око афричког копна, била је условљена променама у индустријском развоју, односно потребом за више сировина и већим тржиштем, али пре свега неопходношћу да се, у ситуацији када често тргујете храном, трговинска размена одвија на што ефикаснији начин. Међутим, поред везе са Индијом као дугорочним коначним циљем, британски трговци, подржани од владе, били су посебно заинтересовани за коришћење широких могућности које су пружала сировинска богатства Османског царства. Британски путници и трговци који су током тридесетих година посетили Царство вратили су се у метрополу са јасном свешћу о његовим привредним потенцијалима и стратешком значају за Велику Британију. Поред тога, у раздобљу од 1827. до 1853. британски извоз индустријских производа у Османско царство порастао је са 1.078.920 на 8.489.100 фунти и достигао $3 \%$ укупног британског извоза, ${ }^{3}$ стављајући Царство испред држава попут Русије, Аустрије, Француске или Апенинског полуострва, односно италијанских државица. Нови изузетан положај који је Османско царство стекло у концепцијама британске спољне политике после 1833. био је у значајној мери условљен колико геостратешким толико и привредним значајем за британску индустрију. ${ }^{4}$

У годинама које су претходиле Кримском рату, британски трговци покушавали су да на најпогоднијим тачкама на Балканском полуострву створе нова трговачка упоришта у османским лукама и омогуће продор у унутрашњост изградњом неопходне саобраћајне инфраструктуре, укључујући железницу. У лето 1850. на обалама Јадранског мора појавили су се британски бродови и инжењери, уз Портину дозволу и пратиоце, ${ }^{5}$ у потрази за луком на јадранској обали коју би било

\footnotetext{
${ }^{2}$ Yaqub N. Karkar, Railway Development in the Ottoman Empire 1856-1914, New York 1972, 64-65; Shereen Khairallah, Railways in the Middle East 1856-1948. Political and Economic Background, Beirut 1991, 32-34, 48-49; Kurt Grunwald, Türkenhirsch. A Study of Baron Maurice de Hirsch, Entrepreneur and Philanthropist, Jerusalem 1966, 28-29; Walter Rechberger, Zur Geschichte der Orientbahnen. Ein Beitrag zur österreichischungarischen Eisenbahnpolitik auf dem Balkan in den Jahren von 1852-1888 (=Ein Beitrag), рукопис докторске дисертације, Wien 1958, 29.

${ }^{3}$ Године 1848. британски извоз у Османско царство досегао је 11.186 .524 , да би се потом умањио до 1853.

${ }^{4}$ Frank E. Bailey, The Economics of British Foreign Policy 1825-1850, The Journal of Modern History, Volume XII, № 4 (December 1940), Chicago 1940, 449-466.

${ }^{5}$ Босна и Хериеговина за везирована Омер-паше Латаса: исправе из бечког државног архива, сабрао Фердо Шишић, Суботица 1938, 107-108, 112, 212-213. У контексту првих идеја о изградњи железнице,
} 
могуће повезати са Србијом и Београдом квалитетним, за трговину погодним каменим друмом. ${ }^{6}$ Ова настојања обележила су и $1851,{ }^{7}$ а почетком 1852 . појавиле су се вести о намерама британских финансијера да граде железницу од Истанбула до Београда. ${ }^{8}$

Британски планови за отварање балканских тржишта за британску трговину давали су могућност српској привреди да оствари непосреднију везу са европским тржиштима и ослободи се аустријског трговачког монопола, али и увлачили Србију не само у замршене односе великих сила на Балкану и њихове односе са Портом, већ и у сучељавање са османским сизереном са којим је уставобранитељски режим био у добрим односима.

У тренутку када су Британци тражили путеве ка коришћењу привредних ресурса Османског царства, а развој догађаја наметао мисао о железници, Србија је, као и остатак Царства, била далеко од степена привредног развоја који би наметао неопходност обезбеђења бржег транспорта веће количине производа. ${ }^{9}$ Процес постепеног политичког осамостаљења није био праћен променама које би довеле до трансформације заостале, аграрне привреде у развијену, засновану на развоју мануфактуре и постепеној индустријализацији, односно, ове промене биле су споре. ${ }^{10}$ Србија је била превасходно пољопривредна земља, али са доминантним ситним сељачким поседом и неразвијеном пољопривредном производњом, те са процентом сеоског становништва које је и према статистици из осамдесетих година 19. века износило готово $90 \%$ укупног броја становника. ${ }^{11}$ Повољан географски положај на граници двају царстава искоришћен је за развој извозне трговине, односно извоза стоке, док је најзначајнији спољнотрговински партнер била суседна

појаву британских бродова у Јадрану у лето 1850. у потрази за погодном трговачком луком помињала је 1852. и српска штампа у угарском делу Хабзбуршке монархије (Южна пчела, бр. 22, 15. марта 1852).

${ }^{6}$ Фонбланк Стратфорду Канингу, Београд 15. и 30. септембра 1850, № 57 и № 63, Архив Србије (=AC), Foreign Office (=FO) 78/827.

${ }^{7}$ Лемперани Министарству спољних послова Француске, Београд 9. марта 1851, Direction Commerciale № 9, AC, Ministère des Affaires Étrangères, Archives Diplomatiques (=MAE, AD), Correspondance Commerciale (=CCC), Belgrade, 1848-1862, Тоme 2; исти Тиргоу, Београд 26. марта 1852, Direction Commerciale № 37, исто; Фонбланк Стратфорду Канингу, Београд 30. марта 1851, № 16, FO 78/862; исти истом, Београд 23. децембра 1851, № 79, исто.

${ }^{8}$ Босна и Хериеговина за везирована Омер-паше Латаса, 430; Фонбланк Стратфорду Канингу, Београд 23. јануара 1852, № 3, FO 195/383; Лемперани Тиргоу, Београд 7. фебруара 1852, Direction Commerciale № 33, MAE, AD, CCC, Belgrade, 1848-1862, Tome 2.

${ }^{9}$ Momir Samardžić, Roads to Europe. Serbian Politics and the Railway Issue 1878-1881, Pisa 2010, 8, 14-20.

10 John R. Lampe, Financial Structure and the Economic Development of Serbia 1878-1912, рукопис докторске дисертације, University of Wisconsin 1971, 16-19.

${ }^{11}$ Мари-Жанин Чалић, Социјална историја Србије 1815-1941: успорени напредак у индустријализацији, Београд 2004, 58-61, 67-69; Мајкл Паларе, Балканске привреде око 1800 - 1914: еволуиија без развоја, Београд 2010, 87-103; J. R. Lampe, нав. дело, 11-16; Димитрије Ђорђевић, Србија и српско друштво 1880тих година, Историјски часопис, XXIX-XXX, Београд 1983, 414. Према попису из 1884. сеоско становништво у Србији чинило је $87,5 \%$ укупног броја становника. Имајући у виду да су благонаклони статистичари „урбаном“ сматрали популацију варошица са мање од 2000, па чак и са мање од 1000 становника, нема сумње да је број сеоског становништва 1884. био значајно изнад $90 \%$. 
Хабзбуршка монархија, на чије тржиште је било усмерено просечно око $80 \%$ извоза. ${ }^{12}$ Напредовање спољне трговине није, међутим, подразумевало развијеност унутрашњег тржишта. Управо затвореност унутрашњег тржишта, односно непостојање националног тржишта као неопходне везе између унутрашњег, локалног, тржишта и спољне трговине, ${ }^{13}$ било је јасан показатељ неразвијености тржишног система у Србији.

Политички сукоби који су обележили прву деценију владавине уставобранитеља, укључујући и догађаје револуционарне 1848 , као и усмереност пре свега на развој политичких институција модерне државе и њену централизацију, несумњиво су неповољно утицали на динамику привредног развоја Кнежевине, усмеравајући пажњу владајућих кругова на често турбулентну политичку свакодневицу, односно отежавајући осмишљавање целовитог програма привредног развоја. Са друге стране, уставобранитељски режим је, како то истиче Слободан Јовановић, „патио од хроничног дефицита“, ${ }^{14}$ а стална финансијска криза утицала је да влада „у привредним питањима пушта да ствари иду како иду“. ${ }^{15}$ Самим тим, стање државних финансија отежавало је било какво значајније улагање у привредни развој државе. Иста ситуација била је приметна и када говоримо о стању и развоју саобраћајне инфраструктуре, иако је спољна трговина подразумевала транспорт. ${ }^{16}$ Уставобранитељи нису могли да се похвале значајнијим успесима на овом пољу, посебно не у првим годинама после победе над Обреновићима, иако су насути путеви тековина њихове владавине и иако је у државни буџет ушла стална свота за грађење путева. У непрестаном страху да не изазову незадовољство становништва, карактеристичном за све слабе режиме, настојали су да избегну изградњу кулуком као најјефтинијим начином да се дође до неопходне радне снаге, а предвиђена годишња свота од 5000 талира била је далеко од задовољавајуће. ${ }^{17}$

Међутим, без обзира на, из данашње перспективе, негативан биланс делатности уставобранитеља на унапређењу привреде и изградњи путева, за контекстуализацију перцепције идеје о повезивању са јадранском луком 1850-1852. и изградњи железнице 1852. од посебног значаја је чињеница да су крајем четрдесетих и почетком педесетих година уочљива интензивнија настојања усмерена ка бржем развоју привреде. Најзначајнија улога у подстицању улагања у привреду припадала је Илији Гарашанину, ${ }^{18}$ тада министру унутрашњих дела, под чијом надлежношћу су се, поред полиције, војске и здравства, налазили и привреда

\footnotetext{
12 С. Ђ. Милошевић, Спољна трговина Србије од 1843-1875 године, Београд 1902, 34-55; Holm Sundhaussen, Historische Statistik Serbiens 1834-1914 mit europäischen Vergleichsdaten, München 1989, 353356.

${ }^{13}$ Karl Polanji, Velika transformacija: politička i ekonomska ishodišta našeg vremena, Beograd 2003, 69-71.

${ }^{14}$ Слободан Јовановић, Уставобранитељи и њихова влада, Београд 1990, 103.

${ }^{15}$ Исто, 104.

${ }^{16}$ K. Polanji, нав. дело, 70.

${ }^{17}$ С. Јовановић, нав. дело, 82-84.

${ }^{18}$ Никола Вучо, Развој индустрије у Србији у ХІХ веку, Београд 1981, 249.
} 
и саобраћај. ${ }^{19}$ Гарашанин је у честим представкама упућеним Државном савету оштро критиковао непродуктивну економску политику владе, замерајући јој одбацивање бројних предлога за подизање индустрије, као „снаге ... без које ни једна држава велика и снажна постала није“. ${ }^{20}$

У поређењу са претходним раздобљем, подухвати скраја четрдесетих и почетка педесетих били су замашни. После избијања револуције 1848. почела је изградња мале тополивнице у Београду, проширене и усавршене следеће године, а 1851. почели су радови на новим постројењима у Крагујевцу. Повезана са почецима војне индустрије била је и изградња топионице у Мајданпеку, рудишту са богатим слојевима гвоздене и бакарне руде, предвиђеном да постане главни топионичарски центар за будући развој индустрије. ${ }^{21}$ Године 1848 . донета је одлука о оснивању Рударског одељења у Министарству финансија и, поред Мајданпека, почели су рударски радови на Рудној глави, те у Кучајни и Мелници, а прва концесија страним финансијерима уступљена је 1849. једном руском друштву за истраживање, експлоатацију и испирање злата из речних наноса. ${ }^{22}$ Крајем 1851. усвојени су неопходни закони о оснивању економије на Топчидеру ${ }^{23}$ у оквиру које је 1852. отворена „Правитељствена чохара“, прва текстилна радионица (названа „фабрика“) за производњу чохе, гајтана, сукна и других текстилних производа, како за војску тако и за тржиште. ${ }^{24}$ Сви наведени погони - тополивница, топионица и топчидерска чохара - представљају прве индустријске погоне у Србији, зачетке српске индустрије, и њихово оснивање у кратком временском периоду, праћено отварањем пољопривредне школе у топчидерској економији, изградњом првих млинова на парни погон, државне ергеле у Ћуприји и другим подухватима, ${ }^{25}$ указује на присуство нове концепције која је, у оквирима финансијских могућности, подразумевала активнији рад на динамизацији привредног живота Кнежевине непосредно пре појаве идеје о изградњи железнице.

\footnotetext{
${ }^{19}$ Даница Милић, Илија Гараманин и привреда Србије, Илија Гарашанин (1812-1874). Зборник радова са међународног научног скупа одржаног 9. и 10. децембра 1987. поводом 175. годишњице рођења (Ур. Владимир Стојанчевић), Београд 1991, 368-374.

${ }^{20}$ Н. Вучо, Развој индустрије у Србији, 152-153; Д. Милић, Илија Гарашанин и привреда Србије, 374. У једном акту Државном савету Гарашанин је записао: „Куда би Србија за 10 година коракнула, када би јој се индустријални потисак дао!“

${ }^{21}$ Исто, 100-101, 152-154.

${ }^{22}$ Д. Милић, Страни капитал у рударству Србије до 1918, Београд 1970, 40-41, 70. Василије Симић, Из скорашње прошлости рударства у Србији, Београд 1960, 69-70. Неопходно је, ипак, напоменути да, услед банкротства руског друштва, до реализације концесије није дошло. Са друге стране, рудник у Кучајни убрзо је затворен, да би поново био отворен тек 1862.

${ }^{23}$ Сборникъ закона' и уредба', и уредбенны ' указа' изданы' у Княжеству Србіи. (Одъ пошетка 1851. до кониа 1852. године.), VI, Београд 1853, 65; Зборник закона и уредаба у Књажеству Србији у досадањим зборницима нештампаних а изданих од 2. Фебруара 1835. до 23. Октобра 1875. год., 30, Београд 1877, 317-328.

${ }^{24}$ Н. Вучо, Развој индустрије у Србији, 197-198.

${ }^{25}$ Исто, 259-260; С. Јовановић, нав. дело, 93-95; Д. Милић, Илија Гарашанин и привреда Србије, 370; Стојан Петровић, Сто година пољопривредних школа у Србији (1853-1953), Београд 1956, 211.
} 
Поред тога, иако ометана повременим забранама, извозна трговина стоком, пре свега на аустријско тржиште, била је у сталном успону, ${ }^{26}$ подстичући размишљања о неопходности унапређења саобраћајне инфраструктуре као једног од предуслова бржег привредног развоја. Изградња путева који би повезали унутрашњост Србије са главним трговачким путевима, праћена пољопривредном производњом за тржиште, допринела би развоју унутрашњег тржишта такође као предуслову бржег привредног развоја, а посредно и непосредно допринело би и расту спољнотрговинске размене. Међутим, нема сумње да постојећа саобраћајна инфраструктура није могла да одигра улогу интегративног фактора и допринесе одлучујућем искораку на путу ка победи концепта тржишне привреде. ${ }^{27}$ Први кораци ка постављању законских основа савременом начину пројектовања, грађења и одржавања друмова предузети су крајем 1848. Уредба од 18. децембра $1848,{ }^{28}$ допуњена 19. јуна 1852, представљала је прву законску меру о начину грађења путева у Србији, одређујући ширину поштанских и трговачких друмова, сеоских и осталих споредних путева, са нагласком на уређењу и одржавању најважнијих трговачких друмова са прогонима и прокопима. ${ }^{29}$ Иако је разлика између нормативног и стварног била велика, иако су, уопштено гледано, путеви и даље били у лошем стању, а током кишне сезоне често непроходни, нема сумње да се за време уставобранитеља радило на изградњи и поправци путева, посебно када је реч о, за спољну трговину изузетно важном, Цариградском друму који једним делом добија нову трасу. ${ }^{30}$

Упоредо са напорима усмереним на развој привреде и саобраћајне инфраструктуре, владајућа уставобранитељска олигархија и кнез Александар Карађорђевић суочавали су се са изазовима које су им наметали британски планови за непосредније саобраћајно повезивање Србије са путевима британске трговине. Отварање конзулата Велике Британије у Београду 1837. било је превасходно мотивисано политичким циљевима супротстављања даљем јачању руског утицаја у

\footnotetext{
${ }^{26}$ С. Ђ. Милошевић, нав. дело, 34-55; Н. Sundhaussen, нав. дело, 353-356. У време 1850-1852. забележен је значајан раст спољнотрговинске размене, делимично условљен и чињеницом да је 1848-1849. трговинска размена била скромних размера због ратних дешавања на простору јужне Угарске.

${ }^{27}$ М. Паларе, нав. дело, 108-120.

${ }^{28}$ Датуми у основном тексту наведени су према Грегоријанском календару, док су при навођењу извора, било да је реч о архивским документима или периодици, преузети датуми наведени у извору.

${ }^{29}$ Сборникъ законаิ и уредба̂, и уредбень указа, изданы' у Княжеству Србскомъ одъ 1-огъ Януара 1847 до кониа Декемвра 1848, IV, Београд 1849, 206-207; Сборникъ закона' и уредба', и уредбенны' указа' изданы' у Княжеству Србіи. (Одъ пошетка 1851. до конца 1852. године.), VI, 113-115; Н. Вучо, Развој индустрије у Србији, 122-124; исти, Železnički saobraćaj kao faktor privrednog razvoja Srbije u XIX. veku, Acta historico oeconomica Iugoslaviae, V, Zagreb 1978, 171-173.

${ }^{30}$ Милан 3. Влајинац, Згон или кулучење ван места становања од средњег века до наших дана. Прилог историји народног живота и рада, Београд 1932, 397-408. О стању саобраћајница педесетих година најбоље сведочи чињеница да је 1857 , услед лошег стања на путевима, био онемогућен долазак сељака у Београд, што је довело до значајног поскупљења намирница (Владислав Миленковић, Економска историја Београда до светскога рата, Београд 1932, 24, 125-126).
} 
Србији, ${ }^{31}$ док о конкретнијим корацима на успостављању непосреднијих трговачких веза до 1850. готово да није било речи. ${ }^{32}$ Наравно, то није значило да трговина између Велике Британије и Србије није постојала, али је њен обим био незнатан, одвијала се преко Трста, најзначајније аустријске луке на Јадрану, а нису били ретки случајеви да на путу од мора до српске границе роба буде задржавана или оштећена. ${ }^{33}$ Од лета 1850 . Британци трагају за погодном луком на јадранској обали преко које би, изградњом пута према српској граници, била могућа неометана трговинска размена са Србијом. Неколико лука на албанској обали, пре свега Љеш, као и херцеговачке луке Клек ${ }^{34}$ и Суторина ${ }^{35}$, смештене на два уска појаса копна који су били део Османског царства, односно бар формално нису били под аустријском контролом, били су потенцијалне тачке уласка британске робе на овај део Балкана и изласка српског извоза на британско тржиште. ${ }^{36}$

Иако је простор преко којег је требало да пређе замишљени пут ка мору био почетком педесетих година 19. века поприште крвавих сукоба и експедиција османске војске са задатком његове „пацификације“, 37 Британци су добили начелну сагласност Порте и обећање да ће бити изграђен део пута од морске обале до српске границе, а на благонаклон пријем наишли су и у Србији. У његовој позадини налазила се жеља за еманципацијом српске трговине од аустријског монопола, поменута још у Заховом Плану, а прихваћена и продубљена у Гарашаниновом Начертанију. ${ }^{38}$ Поред тога, управо у контексту Гарашаниновом руком скицираних

\footnotetext{
${ }^{31}$ Радош Љушић, Кнежевина Србија (1830-1839), Београд 1986, 358-359; Јелена Пауновић-Штерменски, Урквартово виђење међународног положаја Србије, Београд 2007, 114-116; Александар Растовић, Велика Британија и Србија (1878-1889), Београд 2000, 15-24; Чедомир Антић, Велика Британија, Србија и Кримски рат (1853-1856). Неутралност као независност, Београд 2004, 3-4.

32 Радомир Поповић, Аврам Петронијевић, рукопис докторске дисертације, Београд 2009, 231-232. Истицањем превасходно политичког значаја отварања британског конзулата у Београду не желимо да занемаримо увек присутне привредне интересе који су стајали иза корака британске дипломатије. Под утицајем Дејвида Уркварта, британски министар спољних послова лорд Палмерстон истицао је да Србија, поред примарног значаја као препреке ширењу руског интересног простора, представља и тачку привредне пенетрације на Балкан (Ј. Пауновић-Штерменски, нав. дело, 114-115). У том смислу сачињене су и инструкције првом британском конзулу Хоџесу (FO 78/312) и он је 1837. упутио у Лондон извештај о економским могућностима Србије и њеном извозу (FO 78/312). Међутим, у извештајима британског конзула из Београда у време 1837-1849. привредна питања готово се не помињу. У једном тренутку, Фонбланк је 1842. предлагао снабдевање британске флоте усољеним месом из Србије (FO 78/485), али све до 1850. у извештајима се не помињу конкретна настојања на интензивирању трговинске размене између две државе.

${ }^{33}$ Фонбланк Стратфорд Канингу, Београд 11. фебруара 1850, № 7, FO 78/828; Фонбланк Бидвелу, Београд 20. маја 1850 , № 7 , исто.

${ }^{34}$ Место јужно од ушћа Неретве у Јадранско море.

${ }^{35}$ Место у Боки которској, западно од Херцег Новог.

${ }^{36}$ М. Бан И. Гарашанину, Београд 22. фебруара 1851, АС, Фонд Илије Гарашанина (=ИГ)-783; Фонбланк Стратфорд Канингу, Београд 15. и 30. септембра 1850, № 57 и № 63, FO 78/827.

${ }^{37}$ Васиљ Поповић, Аграрно питање у Босни и турски нереди за време реформног режима Абдул-Мецида (1839-1861), Београд 1949, 98-116; Бранко Павићевић, Стварање чрногорске државе, Београд 1955, 302322.

${ }^{38}$ Р. Љушић, Књига о Начертанију: национални и државни програм Кнежевине Србије (1844), Београд 1993, 141-142, 162-163. У извештају из Београда још почетком 1850. Фонбланк је посебно поменуо
} 
основа спољне политике Србије, односно тежње сваке националне државе да државне границе поистовети са границама перципираног етничког простора, ${ }^{39}$ саобраћајно повезивање са Јадраном несумњиво би водило ка успостављању ближих веза са Црном Гором и снажењу утицаја Србије на простору Старе Херцеговине, Босне и Далмације на којем је Гарашанин управо почео са стварањем мреже владиних повереника задужених да у погодном тренутку подигну устанак за уједињење са Србијом. ${ }^{40}$

Имајући у виду вишеструку корист од успостављања ближих веза са јадранском обалом, српски кнез и владајући кругови били су наклоњени овом плану. Крајем лета 1850. Париз и Лондон посетио је Петар Јокић, особа од поверења кнеза Александра, са задатком да преговара о успостављању ближих трговачких веза. ${ }^{41}$ Складишта за српски извоз требало је да буду у Карановцу или у карантину у Рашкој, граничној тачки и будућем споју српске и османске деонице пута ка мору. ${ }^{42}$ У настојању да дође до одговора на питање о најповољнијој траси ка Јадрану Гарашанин је ангажовао Матију Бана, који је значајан део претходне две године провео у Дубровнику организујући мрежу српских пропагандиста. ${ }^{43}$ Разматрајући могуће трасе - „друм херцеговачки“, са излазом на обалу код Клека, и „друм арнаутски“, са излазом код Љеша, Бан се, као Дубровчанин, али и сматрајући да прва траса више одговара политичким циљевима Србије, залагао за излаз код Клека. ${ }^{44}$

Са друге стране, прагматичнији Британци били су свесни да узак појас земљишта у Херцеговини, притешњен између аустријских обала, није најповољније решење, те су закључили да Љеш треба да буде тачка са које ће, преко Рашке, британска роба улазити у Србију. ${ }^{45}$ На овакву одлуку упућивао је и непријатељски

Гарашанинову жељу да аустријска трговина буде делимично потиснута са српског тржишта (Фонбланк Стратфорд Канингу, Београд 11. фебруара 1850, № 7, FO 78/828).

${ }^{39}$ Ернест Гелнер, Нације и национализам, Нови Сад 1997, 11-12.

40 Драгослав Страњаковић, Влада уставобранитеља 1842-1853. Унутрашња и спољашња политика, Београд 1932, 300-311; Душан Берић, Илија Гарашанин и устанак у Херцеговини 1852-1854, Илија Гарашанин (1812-1874), 339-350; Миомир Дашић, Додири и везе ирногорских брдских племена и Србије у доба владавине уставобранитељског режима, исто, 435-452.

${ }^{41}$ Фонбланк Стратфорд Канингу, Београд 15. септембра 1850, № 57, FO 78/827.

${ }^{42}$ Исти истом, Београд 30. септембра 1850, № 63, исто.

${ }^{43}$ Јеремија Д. Митровић, Рад Матије Бана у Дубровнику 1848-1850. по налогу владе Србије и Илије Гарашанина, Илија Гарашанин (1812-1874), 361-368.

${ }^{44}$ М. Бан И. Гарашанину, Београд 22. фебруара 1851, АС, ИГ-783; Лемперани Тиргоу, Београд 9. марта 1851, Direction Commerciale № 9, MAE, AD, CCC, Belgrade, 1848-1862, Tome 2.

${ }^{45}$ Фонбланк Стратфорд Канингу, Београд 30. септембра 1850, № 63, FO 78/827. Из извештаја из 1851. и 1852. несумњиво се намеће овакав закључак јер се увек помиње Љеш као тачка до којег или од којег треба обезбедити сигуран превоз робе. Интересантан је податак да је Фонбланк у поменутом извештају № 63 од 30. септембра 1850. предложио Форин офису да Порта Србији на управу уступи узак појас земљишта од српске границе до албанске обале као најбољи начин да овај пут буде што пре изграђен. Иако је у једном од каснијих извештаја навео да је одустао од ове идеје (Фонбланк Стратфорду Канингу, Београд 23. децембра 1851, № 79, FO 78/862), она ће ући у његов предлог о стварању поткраљевине Србије из новембра 1853. према којем је, између осталог, „територијално проширење Србије требало да обухвати земље до реке Искар у Бугарској, од њеног ушћа у Дунав до изворишта, затим Нови Пазар и део 
став који је Аустрија - све озбиљније угрожена продором британске робе у унутрашњост Балкана и страхујући од опадања значаја тршћанске луке - заузела према покушају британског уласка у Јадран. Аустријске дипломате инсистирале су месецима на Порти да буде усвојен став о затворености Клека и Суторине за османске бродове, страхујући да се иза покушаја Порте да користи луке за снабдевање трупа у Босни и Херцеговини и трговину сољу, као и иза идеје о повезивању Клека и Суторине каналом, актуелне крајем 1850, крије покушај британске владе да обезбеди улазну тачку за преузимање трговине сољу на овом простору. ${ }^{46}$ Повезане са овим настојањима несумњиво су биле и вести о протесту аустријског канцелара принца Шварценберга против отварања албанских лука за британску трговину, као непријатељске демонстрације против тршћанске луке. ${ }^{47}$ Поред тога, пажњу аустријске дипломатије привукло је и путовање британског публицисте Томаса Сквина - према Радосављевићевом мишљењу агента британске владе - у Србију и Босну у мају-јуну 1851, односно гласине о изградњи железнице од Београда до Јадранског мора, са излазом на обалу у Клеку. ${ }^{48}$

Иако су на путу остварења идеје копненог каменог друма из Србије према Јадрану стајале разноврсне препреке - од финансијских проблема Порте и стварне спремности за остварење пројекта, преко вероватног непријатељског става локалног становништва на траси од српске границе ка Јадрану, до противљења аустријске дипломатије уласку британских бродова у Јадран - она је у већој или мањој мери била присутна током целе 1851, о њој се говорило и у првој половини 1852, а средином исте године била је додатно актуелизована и доласком британских пословних људи из Манчестера (Manchester Goods \& Sheffield Cutlery) који су пре краја године покренули замашан пројекат прераде свињетине и извоза преко Смедерева. ${ }^{49}$ У вези са могућим отварањем пута ка Јадрану вероватно су били и радови на изградњи дела пута од Рашке према Карановцу, важној деоници ове трасе унутар граница Србије, праћени радовима на изградњи путева у унутрашњости ради олакшања унутрашње трговине. ${ }^{50}$

Дакле, иако је почетком педесетих развој српске привреде био и даље далеко од нивоа који се сматра почетним степеном индустријске револуције, године које су претходиле британској железничкој иницијативи 1852. обележили су напори државе на динамизацији привредног развоја и унапређењу саобраћајне инфраструктуре, праћени плановима о еманципацији српске трговине од

Горње Албаније који би Србији омогућио добар и брањив гранични појас северно од луке Улцињ и јужно од луке Љеш“ (чл. 3), при чему би поменуте луке постале „слободне луке за трговину свих народа који стоје у савезу с Портом“ (чл. 8) (Ч. Антић, нав. дело, 71, 146-147).

${ }^{46}$ Босна и Хериеговина за везировања Омер-паме Латаса, 193-198, 200-203, 208-209, 210-215, 217, 219220, 226-229, 247-248, 257, 275-276, 297-299.

${ }^{47}$ Фонбланк Стратфорд Канингу, Београд 30. март 1851, № 16, FO 78/862.

${ }^{48}$ Босна и Хериеговина за везировања Омер-паме Латаса, 343-346, 349-355.

49 Лемперани Тиргоу, Београд 26. марта 1851, Direction Commerciale № 37, MAE, AD, CCC, Belgrade, 1848-1862, Тоте 2; исти истом, Београд 14. јун 1852, Direction Commerciale № 40, исто; Фонбланк Малмсберију, Београд 8. јула 1852, № 9, FO 78/900; исти истом, Београд 19. августа 1852, № 12, FO 195/383; исти истом, Београд 31. децембра 1852, № 23, исто; Србски дневник, бр. 34, 9. октобра 1852.

${ }^{50}$ Србски дневник, бр. 21, 30. августа 1852. 
аустријског монопола изградњом пута према Јадрану - квалитетно пројектованог и изграђеног, за трговину погодног, каменом насутог друма. Међутим, почетком 1852. појавиле су се вести у страној штампи о плановима британских финансијера да граде железницу од османске престонице до Београда. ${ }^{51}$ Ови планови наметали су српском кнезу Александру Карађорђевићу и уставобранитељској олигархији неопходност заузимања става у вези са овим питањем.

Први предлог о изградње железнице у Србији датира из $1837,,^{52}$ у службеним Србским новинама још средином четрдесетих прижељкивана је њена изградња на територији Кнежевине, ${ }^{53}$ а почетком педесетих образованим Србима идеја изградње железнице није била страна. ${ }^{54}$ Нема, међутим, доказа да су кнез и уставобранитељска олигархија размишљали о изградњи железнице кроз Србије упркос актуелности идеје отварања пута ка Јадрану. Историја изградње српске железнице, па и идеја које су јој претходиле, потврда је тезе о спољнополитичкој условљености њихове изградње, односно доказ да је развој саобраћајне инфраструктуре, а посебно железница, на европској географској и економској периферији значајно претходио општем привредном развоју. ${ }^{55}$ Железницу као тему наметали су интереси великих сила и у Београду су о њој почели да размишљају тек када су били принуђени спољнополитичким разлозима, односно вестима о делатности британских инжењера у Истанбулу.

Убрзо после објављивања вести у страној штампи о путу британских инжењера, пре него што су стигле вести о преговорима с Портом и евентуалним резултатима преговора, у разговору са аустријским конзулом Теодором Радосављевићем крајем јануара 1852. кнез Александар је изјавио да је његова жеља да деоница на територији Србије буде изграђена од стране аустријског друштва, поменувши експлицитно као пожељног финансијера будуће српске железнице барона Георгиоса Сину, аустријског банкара грчког порекла, у том тренутку вицегувернера Аустријске нащионалне банке (Österreichische Nationalbank). ${ }^{56}$ Прве

\footnotetext{
51 Фонбланк Стратфорду Канингу, Београд 23. јануара 1852, № 3, FO 195/383; Босна и Хериеговина за везирована Омер-паше Латаса, 430; Лемперани Тиргоу, Београд 7. фебруара 1852, Direction Commerciale № 33, MAE, AD, CCC, Belgrade, 1848-1862, Tome 2.

${ }^{52}$ Момир Самарџић, Посета барона Хердера Србији и први план за изградњу железнице, Истраживања 18, Нови Сад 2007, 140-141.

${ }^{53}$ Србске новине, бр. 24, 24. марта 1845; Јездимир С. Николић, Историја железница Србије, Војводине, Црне Горе и Косова, Београд 1980, 18-19. У тексту о царинским односима Србије са суседним државама помиње се потреба да се влада побрине за изградњу насутог пута, а у догледно време и железнице.

${ }^{54}$ Ђорђе Ђурић, Вук Маринковић, биографија и научни рад утемељивача физике као модерне науке у Србији, Нови Сад 2007, 63-64. У светосавској беседи 1851. Маринковић је говорио о гвозденим путевима који треба да „као мрежа горе наше и долине изплету“.

${ }^{55}$ I. T. Berend, G. Ránki, нав. дело, 130.

${ }^{56}$ Босна и Хериеговина за везировања Омер-паме Латаса, 430; W. Rechberger, Ein Beitrag, 30; A. Lanier, Die Geschichte des Bank- und Handelshauses Sina, Frankfurt / M. - Berlin 1998, 135-146. О овој теми кнез и Радосављевић су разговарали крајем јануара и почетком марта 1852. Према досадашњим сазнањима, било је то први пут да је у званичним контактима представника српске државе са конзулима страних држава поменуто питање изградње железнице. О првим корацима владе у вези са изградњом железнице први је, у раду посвећеном двадесетпетогодишњици пуштања у промет железнице Београд-Ниш, писао
} 
реакције у Београду указале су на суштину става који ће Србија заузети у вези са овим питањем. Британски планови о каменом друму према Јадрану подразумевали су да ће Србија самостално одлучивати о свим сегментима усавршавања и изградње путне мреже на својој територији, те је ова идеја наишла на одобравање у Београду, а кнез је у Париз и Лондон послао Петра Јокића, као особу од личног поверења, са задатком да укаже на значај који Србија придаје успостављању трговачких веза са западним силама и отварању пута према Јадрану. ${ }^{57}$ Са друге стране, натписи у страној штампи о путовању инжењера у Истанбул указивали су да би железнички пројекат требало да буде британско-османски, иако је подразумевао пролазак линије преко територије Србије. Другим речима, о изградњи железнице преко територије Кнежевине требало је да се одлучује изван њених граница и без консултација са кнезом и владајућим круговима у Београду. Због тога је суштину државне политике чинио став да је изградња железнице на територији Србије као аутономне кнежевине у оквиру Османског царства питање о којем није могуће одлучивати без консултовања српског кнеза и владе.

Један од начина супротстављања намерама Порте било је и самостално одлучивање о будућем концесионару, независно од Портиних преговора са британским финансијерима. Логичан избор било је окретање суседној Аустрији која је интензивно приступала изградњи железничке мреже на својој територији. У том смислу, као најпогоднија личност за покретање ове теме пред Радосављевићем био

Таса Ђ. Ивковић. Том приликом Ивковић је навео да је кнез Александар Карађорђевић 1851. први на Порти покренуо питање изградње железнице преко територије Србије, али да није наишао на добар пријем у Цариграду (Таса Ђ. Ивковић, Споменица двадесетпетогодищњице српских државних железница: од 3. Септембра 1884. до 3. Септембра 1909. год, Београд 1909, 3-4). Његове тврдње преузели су каснији писци повеснице српских железница (Драгомир Арнаутовић, Историја Српских железница 1850-1918, Београд 1934, 18-19; исти, Histoire des chemins de fer Yougoslaves 1825-1937, Paris 1937, 38; Петар Миленковић, Историја грађења железница и железничка политика код нас (1850-1935), Београд 1936, 11-12; Jovan Raičević, Železnice u Srbiji 1884-1958, Privredna hronika VI, Beograd 1959, 8-9; Ђурађ Мрђеновић, Гвоздени пут Србије, Београд 1974, 28; Ј. С. Николић, нав. дело, 31; Милан Грујић, Зоран Бундало, Железнице Србије, Београд 2004, 24), као и Даница Милић у тексту о железничком питању у Србији средином 19. века (D. Milić, Die Pläne zum ausbau der Eisenbahn in Serbien in der Mitte des 19. Jahrhunderts, Eisenbahnbau und Kapitalinteressen in der Beziehungen der Österreichischen mit den Südslawischen Ländern (Hrsg. R. G. Plaschka), Wien 1993, 32), иако не постоје сачувани савремени историјски извори који би говорили у прилог Ивковићевим наводима. Поред тога, сумњу у датирање побуђује и податак - на чију проблематичност је указао већ Арнаутовић (D. Arnaoutovitch, Histoire des chemins de fer Yougoslaves, 41) - да је Ивковић у исту годину сместио и инцидент с британским инжењерима. Међутим, нема сумње да се поменути инцидент догодио 1852. јер о томе говоре извештаји француског, британског и аустријског конзула у Београду из јуна исте године. Према нашем мишљењу, могуће је да се разлог за овакву погрешку налази у чињеници да је поменуто Ивковићево дело писано као пригодан текст поводом обележавања двадесет пет година од пуштања у саобраћај прве српске железнице, недуго пошто је дошло до смене династија, те је на овај начин истакнута улога оца краља Петра Карађорђевића у промовисању идеје изградње железнице у Србији. Познати историјски извори, међутим, не остављају никакву сумњу у вези са хронолошким оквирима проблема насталих у вези са појавом британских инжењера у Истанбулу и њиховим каснијим доласком у Србију, док нема никаквог помена о било каквом самосталном кораку на Порти који би томе претходио.

${ }^{57}$ Фонбланк Стратфорд Канингу, Београд 15. септембра 1850, № 57, FO 78/827; Д. Страњаковић, нав. дело, 135-136. 
је кнез Александар који се у унутрашњополитичким сукобима са уставобранитељском олигархијом у Државном савету и обреновићевском опозицијом, сукобима који су у пролеће 1852. били све израженији, ослањао управо на подршку аустријског конзула. Промена у аустријском конзулату крајем 1850, праћена подизањем нивоа дипломатског представништва са конзулата у генерални конзулат, означила је почетак успона аустријског утицаја, а Радосављевић је, поред Срба из Хабзбуршке монархије који су били на високим државним положајима у Србији, посебну пажњу усмерио на кнеза и његове саветнике, убеђујући их недуго после доласка у Београд „да им Аустрија, као суседна сила, може највише помоћи у случају крајње потребе и да они могу на њену помоћ рачунати“. 58

Међутим, став српског кнеза према идеји изградње железнице кроз Србију од стране британских финансијера довео је аустријског конзула у незгодан положај. Суседна монархија била је начелно заинтересована за спречавање продора британског капитала и индустријских производа у унутрашњост Балканског полуострва и имала је финансијских могућности да учествује у изградњи железнице кроз Србију, али влада у Бечу није у том тренутку била спремна да разматра питање железничког повезивања са Османским царством преко Србије. Иако је угарски парламент још 1836. усвојио план будуће железничке мреже на којем се налазила линија Пешта-Земун, ${ }^{59}$ преузимање надзора над угарским железницама од стране аустријске владе у марту 1850 . представљало је корак уназад. План аустријске владе из 1851. о изградњи железница на територији Хабзбуршке монархије био је у погледу изградње железница према Истоку усмерен на повезивање монархије са Османским царством и излазак на Црно море преко Трансилваније и дунавских кнежевина Влашке и Молдавије, док је према југу ишла тек једна споредна линија према Дунаву. Из Беча су у првом реду тежили да добију железничку везу с лукама Браилом и Галцом и румунском обалом према Бугарској. Аустријски Drang zum Meer био је средином XIX века условљен привредним, политичким и стратешким интересима монархије на Истоку. Са једне стране, нерегулисан ток Дунава и помањкање других саобраћајних веза с подручјем доњег Дунава представљали су велику препреку аустријској трговини, док је, са друге стране, монархија на овом простору, као и осталим балканским провинцијама Царства, покушавала да се избори с трговачком конкуренцијом западних држава, често се служећи и дипломатским притиском на Порту, о чему је сведочио и отпор уласку британских трговачких бродова у Јадран. Са погледом усмереним према дунавским кнежевинама, перципираним као најпогоднији пут за успешну борбу са трговачком конкуренцијом Велике Британије и Француске, аустријска дипломатија није у том тренутку била заинтересована за железничко повезивање са Османским царством преко територије Србије. ${ }^{60}$ Ситуацију је додатно усложњавала чињеница да је

\footnotetext{
${ }^{58}$ Д. Страњаковић, нав. дело, 159-171; В. Поповић, Политика Франиуске и Аустрије на Балкану у време Наполеона III, Београд 1925, 45-46; Ч. Антић, нав. дело, 7-15.

${ }^{59}$ Намера угарског парламента да успостави железничку везу са Србијом изражена је још једном 1848.

60 W. Rechberger, Ein Beitrag, 29-32; исти, Zur Geschichte der Orientbahnen: Österreichische Eisenbahnpolitik auf dem Balkan (=Österreichische Eisenbahnpolitik), Österreichische Osthefte 5, Wien 1960, 348-350; Gerhard Rosegger, John H. Jensen, Transylvanian Railways and Access to the Lower Danube 1856-
} 
Србија била вазална кнежевина, те није имала право склапања међународних уговора (ius contrahendi) независно од Порте. ${ }^{61}$

$\mathrm{Ca}$ друге стране, суштински заинтересовани за спречавање продора британског капитала и индустријских производа у унутрашњост Балканског полуострва, владајући кругови у Бечу нису могли да не буду забринути услед вести које су стигле у марту 1852. о идеји коју је у Београду промовисао драгоман амбасаде Велике Британије у Истанбулу Алисон ${ }^{62}$ о комбиновању идеје пута ка Јадрану и железнице према Истанбулу изградњом железнице која би из османске престонице ишла преко Ниша до Јадрана, са огранком преко Алексинца до Београда. $^{63}$ Иако је сам Алисон у Сарајеву пред аустријским конзулом Атанацковићем за железницу према Скадру, односно Љешу, говорио да „спада у царство немогућих ствари“ услед финансијске ситуације у којој се Царство налазило и одбијања Порте да се дугорочно задужи, аустријском конзулу није промакло да је британски драгоман сарајевским трговцима ипак говорио о предностима трговачког пута према Јадрану. ${ }^{64}$

У таквој ситуацији, имајући у виду неопходност очувања утицаја Монархије у Србији, влада у Бечу није се одмах отворено изјаснила о предлогу кнеза Александра да аустријско друштво гради српску железницу. ${ }^{65}$ Извештаји из Истанбула деловали су умирујуће у вези са остварењем идеја која је Алисон представио у Београду, ${ }^{66}$ али је даљи развој догађаја наметнуо неопходност јаснијег

1914, East European Quarterly XXIX, 4 (January 1996), Boulder 1996, 428-429; Dževad Juzbašić, Izgradnja željeznica u Bosni i Hercegovini u svjetlu austrougarske politike od okupacije do kraja Kállayeve ere, Sarajevo 1974, 7; Janos Majdan, A magyar-szerb vasúti kapcsolatok kiépülése, Српско-мађарски односи кроз историју: зборник радова са међународног научног скупа одржаног 15. јуна 2007. године у Новом Саду (Ур. Золтан Ђере), Нови Сад 2007, 257-262; М. Самарџић, Железничко питање у спољној политици Србије 18781888, рукопис докторске дисертације, Нови Сад 2007, 23-24.

${ }^{61}$ Драгутин П. Ђетвај, Развој међународног уговорног капащитета Србије у ХІХ веку, Суботица 1939, 3132.

${ }^{62}$ Разлог доласка Алисона у Београд било је решавање спора између српске владе и британског конзула Фонбланка насталог услед разбијања прозора на конзулату 11. октобра 1851. које је довело до привременог затварања конзулата. После дугих преговора, који су подразумевали учешће Порте, британског амбасадора у Истанбулу, као и српског капућехаје, уследила је Алисонова посета Београду. Спор је коначно решен 4. априла 1852. поновним истицањем британске заставе праћеним топовском канонадом из артиљеријске касарне (Д. Страњаковић, нав. дело, 168-172).

${ }^{63}$ Босна и Хериеговина за везировања Омер-паме Латаса, 440-441.

${ }^{64}$ Исто, 450. Из Атанацковићевог извештаја, као и из писања српске штампе у Угарској (Южна пчела, бр. 22, 15. марта 1852; бр. 23, 19. марта 1852), која је преносила писање загребачког листа на немачком језику Аграмер иајтунга (Agramer Zeitung), те француског листа Журнал де деба (Journal des Débats, 16. фебруара 1852), који је преносио писање немачког Келнише цајтунга (Kölnische Zeitung), видљиво је да су јавности у Хабзбуршкој монархији биле познате гласине о британским намерама да граде пут од Скадра ка Србији и Дунаву. Интересантно је да је истовремено у најугледнијем немачком дневном политичком листу Алгемајне цајтунг (Allgemeine Zeitung) изашао чланак који је промовисао идеју изградње линије Београд-Солун као трасе која највише одговара интересима немачко-аустријске индустрије (целокупан текст чланка у: D. Arnaoutovitch, Histoire des chemins de fer Yougoslaves, 39).

${ }^{65}$ W. Rechberger, Ein Beitrag, 30.

${ }^{66}$ Босна и Хериеговина за везирована Омер-паме Латаса, 459-460. 
дефинисања политике Монархије према железничком повезивању са Османским царством преко Србије.

Крајем априла у Истанбулу се појавила нова група британских инжењера, ${ }^{67}$ представника финансијског друштва Fox, Brassy \& Co, ${ }^{68}$ са задатком да преговарају о изградњи линије Истанбул-Београд. Почетни преговори са Портом завршени су одобрењем да инжењери друштва изврше проучавање терена на главној линији која би од Истанбула, преко Једрена, Пловдива, Софије, Ниша, Алексинца, Параћина, Ћуприје, Јагодине и Смедерева ишла до Београда, док би споредна линија излазила на Дунав код Видина. ${ }^{69}$ Почетком јуна у Београду су се појавила четири инжењера друштва - Едвард и Метју Лихи, Серафин Гебеји и Фридрих Браунсон - са Портиним ферманом који им је дозвољавао обављање неопходних испитивања трасе. $^{70}$ Српски кнез и влада нити су обавештени о њиховом доласку у Србију, нити је од њих захтевано одобрење за планирана мерења. Стигавши у српску престоницу, јавили су се османском команданту тврђаве Куршид-паши, разговарали су и са представницима великих сила, али нису учинили службену посету кнезу Александру. ${ }^{71}$ Убрзо су напустили Београд и Србију, нејвероватније у смеру Видина. ${ }^{72}$

${ }^{67}$ Исто, 495-496.
${ }^{68}$ Ч. Антић, нав. дело, 168.
${ }^{69}$ Конзул Француске у Београду министру спољних послова Француске, Београд 16. јуна 1852, Direction
Commerciale, № 40, МАЕ, АD, ССС, Belgrade, 1848-1862, Tome 2.
${ }^{70}$ Босна и Херцеговина за везировања Омер-паше Латаса, 520. Радосављевић у извештају помиње да су
инжењери стигли пре пет дана, дакле вероватно 6. јуна 1852.
${ }^{71}$ Исто; конзул Француске у Београду министру спољних послова Француске, Београд 16. јуна 1852, Direction Commerciale, № 40, MAE, AD, CCC, Belgrade, 1848-1862, Tome 2; Фонбланк Малмзберију, Београд 9. јуна 1852, № 19, FO 195/383. Није извесно да ли су инжењери пре доласка у Београд обавили неопходна мерења. Из писања штампе, као и из наведених извештаја страних конзула у Београду о разговору са инжењерима, могло би се закључити да су они стигли у Србију копненим путем, пратећи трасу будуће железнице, те да су због тога били упознати са проблемима са којима би могли да се сусретну приликом изградње железнице. На исти закључак упућује и непоуздани Таса Ђ. Ивковић, као и остали писци повеснице српских железница, несумњиво на основу његових тврдњи. Према најдетаљнијим наводима (Т. Ђ. Ивковић, нав. дело, 3-4, Д. Арнаутовић, Историја Српских железница, 19), локалне власти су обавестиле кнеза о доласку инжењера, те их је он позвао у Београд, разговарао са њима и љутито реаговао када су му саопштили разлоге своје посете. У сачуваној архивској грађи Министарства унутрашњих дела, Внутреног и Иностраног одељења Министарства иностраних дела, те Државног савета, нисмо успели да пронађемо никакво сведочанство о доласку британских инжењера и њиховом боравку и радовима на територији Кнежевине, односно о обавештењима локалних власти о њиховој делатности. Без обзира на то, сматрамо да извештаји страних конзула пружају довољно доказа да можемо да претпоставимо да су одређена мерења заиста обављена, у крајњој линији да су инжењери у Србију стигли копненим путем и прешли пут од Алексинца до Београда. Са друге стране, извесно је да Ивковићеве тврдње о посети кнезу нису тачне.

${ }^{72}$ Босна и Херцеговина за везировања Омер-паше Латаса, 520. Према наводима Тасе Ђ. Ивковића (Т. Ђ. Ивковић, нав. дело, 3-4), које је преузела већина аутора повеснице српских железница (П. Миленковић, нав. дело, 11-12; Ђ. Мрђеновић, нав. дело, 28; Ј. С. Николић, нав. дело, 31; М. Грујић, 3. Бундало, нав. дело, 24) као и Даница Милић (D. Milić, Die Pläne zum ausbau der Eisenbahn in Serbien, 32), британски инжењери протерани су из Србије. Интересантно је, међутим, напоменути да се у извештајима представника великих сила у које смо имали увид (Аустрија, Велика Британија, Француска) не помиње 
Одлазак инжењера из Београда није значио и пропаст идеје о трансбалканској железници. Преговори у Истанбулу између британских финансијера и Порте о уступању концесије тек су предстојали, а кнез, Државни савет и влада у Београду морали су да учине све неопходно да заштите интересе Србије. Специфичност политичке ситуације у Кнежевини - све отворенији сукоб између кнеза и Савета, смрт Аврама Петронијевића, кнежевог представника и министра иностраних дела и једног од најзначајнијих и најугледнијих представника уставобранитеља, као и вишемесечно одсуство Илије Гарашанина, друге утицајне личности режима - одређивала је, у значајној мери, тренутни став према британском пројекту. У одсуству утицајнијих личности режима, кнежева улога у доношењу политичких одлука била је приметнија, а његово лично незадовољство поступком британских инжењера, грађана државе са чијим представником у Београду је имао лоше односе, одлучујуће је утицало на неуспех њихове мисије у Србији. Са друге стране, чињеница да су политички сукоби у земљи водили ослањању појединих политичких групација на дипломатске представнике појединих великих сила, омогућила је изузетан утицај појединих конзула, али и Порте, на чију се подршку уставобранитељски режим ослањао. ${ }^{73}$

Управо раније ослањање на Порту и утицај сизерена додатно су усложњавали питање остварења британско-османског железничког пројекта уз подразумевајући прећутни пристанак Београда. Кнез Александар надао се да би уз помоћ аустријске владе било могуће превазићи настале проблеме, како у вези са изградњом железнице у Србији од стране аустријског друштва, тако и у вези са пристанком Порте на овакво решење. Према Радосављевићевом извештају из Београда, пре доласка инжењера о овом питању је у његовом присуству неколико пута било речи и став кнеза и круга око њега и даље је био да изградњу железнице у Србији треба поверити барону Сини или неком другом аустријском предузимачу, уз учешће српске владе. Предвиђено је да српска влада уступи земљиште и на територији Србије по набавној цени обезбеди камен, дрво и остали неопходан грађевински материјал у мери у којој то буде могуће. Новчана вредност материјала и потребна радна снага били би улог српске владе, док би остали трошкови били улог страног предузимача. На тај начин, железница би била заједничко власништво и добит би се делила сразмерно уложеном капиталу. Поред тога, српски кнез надао се да ће влада у Бечу обезбедити пристанак Порте да Србија сама гради железницу, односно да ће спречити интервенцију Истанбула и Лондона против плана који је несумњиво отежавао извођење британског железничког пројекта. Блиски односи

\footnotetext{
протеривање инжењера, већ само незадовољство због непоштовања статуса који је Србија имала у оквиру Османског царства. Протеривање се не помиње ни у чланку у Србском дневнику (бр. 3 од 28. јуна 1852), листу често критичном према српској влади услед веза са Обреновићима (Василије Крестић, Историја српске штампе у Угарској 1791-1914, Нови Сад 1980, 111-112), који несумњиво не би пропустио добру прилику за критику кнеза Александра и уставобранитељског режима. Тиме још једна од основних општеприхваћених Ивковићевих теза долази у питање.

${ }^{73}$ Дејвид Мекензи, Илија Гараманин. Државник и дипломата, Београд 1987, 148-158; Д. Страњаковић, нав. дело, 132-133, 156, 166-172, 176-179.
} 
кнеза и Радосављевића, ${ }^{74}$ али и константна агитација аустријског конзула против овог пројекта, ${ }^{75}$ дозвољавали су првом да експлицитно тражи јасан одговор да ли може да рачуна на заштиту аустријске владе, предлажући истовремено слање у Беч представника опуномоћеног да у том смислу одмах започне неопходне преговоре о овом питању. ${ }^{76}$ Упоредо са тражењем подршке у Бечу, српски капућехаја у Истанбулу Константин Николајевић, кнежев зет, при повратку у османску престоницу средином јуна добио је упутства да протестује против поступка Порте који је, према мишљењима у Београду, био противан аутономним правима Кнежевине. Пре одласка, Николајевић је француском конзулу Полу Реноару говорио о незадовољству кнеза и изјавио да Србија ни под којим условима неће дозволити пословање страним компанијама мимо њене воље. ${ }^{77}$ Помоћ Француске у отпору намерама Порте било је оно чему су се у Београду надали, ${ }^{78}$ не искључујући ни могућност привлачења француског капитала и инжењера у пројекат трансбалканске железнице. ${ }^{79}$

Док је кнез Александар покушавао да обезбеди подршку аустријске владе, у Истанбулу су настављени преговори између Порте и британских финансијера. Крајем августа у европској штампи појавили су се гласови о промени трасе трансбалканске железнице, односно о томе да ће се линија, уместо преко Београда, преко Видина и Влашке спојити са аустријском линијом која ће ићи од Солнока, преко Темишвара и Оршаве, до Калафата. ${ }^{80}$ Овакве вести нису биле без основа. На

\footnotetext{
${ }^{74}$ Према наводима британског конзула, Радосављевић је посећивао кнеза неколико пута дневно, на тај начин активно учествујући у свим државним пословима (Фонбланк Стратфорду Канингу, Београд 12. априла 1851, № 18, FO 78/862).

${ }^{75}$ Радосављевић се и пре доласка британских инжењера у Београд, према властитим речима, „потрудио да ојача у свим приликама (...) одбојност према енглеском грађевинском друштву“ (Босна и Хериеговина за везирована Омер-паме Латаса, 521).

${ }^{76}$ Босна и Хериеговина за везирована Омер-паме Латаса, 521-523.

${ }^{77}$ Реноар Тиргоу, Београд 14. јуна 1852, Direction Commerciale, № 40, MAE, AD, CCC, Belgrade, 18481862, Tome 2

${ }^{78}$ Исти истом, Београд 3. јула 1852, Direction Commerciale, № 41, исто.

${ }^{79}$ Исти истом, Београд 14. јуна 1852, Direction Commerciale, № 40, исто; исти истом, Београд 19. јула 1852, Direction Commerciale, № 42, исто; Министарство спољних послова Француске конзулу у Београду, Париз 7. септембра 1853, № 44, исто.

${ }^{80}$ Journal des Débats, 5. маја 1852; 25. августа 1852; Србски дневник, бр. 11, 26. јула 1852; Д. Арнаутовић, Историја Српских железница, 19; исти, Histoire des chemins de fer Yougoslaves, 41; Ј. С. Николић, нав. дело, 33. Иако је европска штампа повремено од почетка 1852. доносила кратке вести о намерама британских финансијера да граде линију Истанбул-Београд, и без обзира на чињеницу да су ове вести преносили српски листови у јужној Угарској (Южна пчела, бр. 22, 15. марта 1852; бр. 23, 19. марта 1852; бр. 24, 22. марта 1852; Србски дневник, бр. 3, 28. јуна 1852; бр. 8, 16. јула 1852; бр. 11, 26. јула 1852), у Србским новинама, полузваничном гласилу српске владе, овој иницијативи није придавана пажња све до септембра 1852. Додуше, два пута пренете су, у рубрици Прегледъ Южнославенски журнала, кратке вести о чланцима у српским листовима у јужној Угарској - Србском дневнику (чланак од 28. јуна 1852. поменут у Србским новинама 3. јула 1852) и Србско-народном вестнику (чланак од 17. јула 1852. поменут у Србским новинама 22. јула 1852), у којима се помиње железница Истанбул-Београд. Србске новине нису, међутим, пренеле оне делове у којима се наводи да је реч о британском пројекту. Тек у броју 108 Србских новина од 20. септембра 1852, после напомене уводничара да му није познат став владе о
} 
Порти су заиста у једном тренутку изашли са захтевом да железница не иде долином Мораве већ преко Видина. ${ }^{81}$ Међутим, британски преговарачи инсистирали су на овој линији и у предложеној верзији уговора остала је одредба о линији од Истанбула до Београда са деоницом према Видину, уз 6 \% годишње камате на уложени капитал у раздобљу од тридесет година. ${ }^{82}$ Средином септембра преговори су били у завршној фази, а Порта је, према саопштењима једног од браће Лихи отправнику послова у амбасади Велике Британије пуковнику Роузу, коначно одобрила градњу линије. Међутим, негативно расположена према целокупном концепту страних улагања, односно узимања дугорочних зајмова, Порта је захтевала да Царство ни симболично не учествује у финансирању радова, а експлоатација железнице била би ограничена на тридесет година. ${ }^{83}$

Вести о измени трасе указивале су на незадовољство Порте ставом Србије и британске дипломате настојале су да подстакну превазилажење ове препреке. У Истанбулу, пуковник Роуз је разговарао са Николајевићем. Српски капућехаја уверавао га је у жељу Србије да гради железницу, али само као равноправан преговарач. Његово изненађење када му је Роуз поставио питање којим средствима Србија намерава да гради железницу, као и одговор да би могла да их позајми од британског друштва којем Порта уступи концесију, првенствено су указивали на чињеницу да су кнез и његов капућехаја пажњу првенствено поклањали политичкој страни овог питања, док је економска страна била у другом плану. Са друге стране, Роуз је истакао да политички уступак на којем је српски кнез инсистирао не би Србији донео и неопходне привредне резултате, јер би главна линија заобишла Србију. ${ }^{84}$

Упоредо са Роузовом делатношћу у османској престоници, Фонбланк је сличним аргументима у српској престоници промовисао британски железнички пројекат, истичући све административне, политичке, финансијске и привредне разлоге који су ишли у прилог његовом остварењу. ${ }^{85}$ У својим извештајима, Фонбланк је доследно инсистирао на чињеници да је српски отпор пре свега

овом питању, пренет је чланак из француског часописа Журнал де деба (број од 19. септембра 1852) у којем се истиче незадовољство српског кнеза непоштовањем које му је исказано начином на који је Порта решавала ово питање. Могуће је да је изузетак у септембру 1852. учињен због тога јер је тиме указано на став кнеза Александра према овом питању. Не треба, међутим, занемарити две чињенице: (1) овај текст објављен је неколико дана после постављања за кнежевог представника и министра иностраних дела Илије Гарашанина, несумњиво наклоњеног железничком пројекту (Фонбланк Роузу, Београд 10. октобра 1852, № 54, FO 195/383); (2) у пролеће 1852. Јован Мариновић је постигао споразум са листом Журнал де деба о промовисању интереса Србије на његовим страницама (И. Гарашанин Ј. Мариновићу, Париз 19. јуна 1852, Писма Илије Гарашанина Јовану Мариновићу: књига прва: од 29 марта 1848 до 31 дей. 1858, средио Ст. Ловчевић, Београд 1931, 27).

${ }^{81}$ Ч. Антић, нав. дело, 168.

${ }^{82}$ D. Arnaoutovitch, Histoire des chemins de fer Yougoslaves, 43-45. Интересантно је да је, у верзији коју је француски амбасадор Лавалет доставио у Париз, и линија према Видину требало да иде делимично преко територије Србије - преко Гургусовца и Неготина.

${ }^{83}$ Ч. Антић, нав. дело, 168-169.

${ }^{84}$ Исто, 169-170.

${ }^{85}$ Фонбланк Роузу, Београд 12. јула 1852, № 38, FO 195/383; исти Малмсберију, Београд 3. септембра 1852, № 32, исто. 
резултат интрига аустријског конзула и његовог утицаја на кнеза Александра, који се даље, посредством родбинских веза са Николајевићем, преноси и на службени став који Србија заузима пред османским сизереном. ${ }^{86}$ Управо због тога, делатност је усмерио на кнежеве утицајне политичке неистомишљенике. У том смислу, ситуација се значајно изменила повратком Илије Гарашанина у Србију у септембру 1852. Иако су односи кнеза и Гарашанина од 1850 . били често лоши, а сукоб био константно подстицан од људи из кнежевог окружења, унутрашњополитичка ситуација, односно делатност противника уставобранитељског режима, кнеза и владе, али и сукоби у њиховим редовима, захтевали су одлучне мере у циљу подизања ауторитета власти и спречавања немира у унутрашњости. Три дана после Гарашаниновог повратка са лечења у иностранству, кнез га је, пет месеци после смрти Аврама Петронијевића, 25. септембра именовао за представника и министра иностраних дела. ${ }^{87}$

Гарашанин је био међу ретким политичарима који је са Фонбланком, упркос лошим односима српске владе и британског конзула, очувао током дужег временског раздобља односе који би могли да се назову чак и пријатељским. ${ }^{88}$ Његов опрезан став према суседној монархији и наклоност ка западним силама несумњиво су били у основи добрих односа које је нови кнежев представник гајио како према британским, тако и према француским дипломатским представницима у Србији. Своја вишемесечна путовања по Европи ради лечења 1851. и 1852. Гарашанин је искористио и за успостављање непосредних снажнијих контаката са западним силама - у лето 1852. пре свега са француским принцем председником Лујом Наполеоном. ${ }^{89}$

Као министар унутрашњих дела надлежан за привредна и инфраструктурна питања подржавао је британске планове за отварањем трговачког пута ка Јадрану 1850-1852. као могућност ослобођења од монопола суседне монархије на српску трговину. Нови железнички пројекат представљао је нову могућност ка остварењу истог циља. После вести из Истанбула да су Порти уручени коначни планови железничког пројекта, две недеље после преузимања нове дужности Гарашанин је посетио Фонбланка и формално му изјавио „да српска влада дезавуише сваки протест који је у њено име можда учињен против подухвата у којем види велику прилику“, отворено се негативно изјаснивши о страним утицајима везаним за ово питање. Фонбланк је био уверен да је Гарашаниново именовање на нову дужност одлучујући корак ка остварењу железничког пројекта. ${ }^{90}$

Са друге стране, у време Гарашаниновог повратка у Србију, изневерена су надања кнеза Александра у отворену помоћ из Беча. Имајући увек на уму приоритетну железничку везу са румунским кнежевинама, аустријска влада није начелно била противна да подржи жељу кнеза Александра да аустријски

\footnotetext{
${ }^{86}$ Исти Малмсберију, Београд 3. септембра 1852, № 32, исто.

${ }^{87}$ Д. Страњаковић, нав. дело, 138-142, 179-180.

${ }^{88}$ Ч. Антић, нав. дело, 9.

${ }^{89}$ Д. Мекензи, нав. дело, 149-162.

${ }^{90}$ Фонбланк Роузу, Београд 10. октобра 1852, № 54, FO 195/383.
} 
финансијери и предузимачи граде српску железницу, те на тај начин отежају продор британског капитала и трговаца на Балкан, али су били свесни проблема који су произлазили из међународноправног положаја Србије и неспремности Порте на дугорочно задуживање на страном финансијском тржишту. У том смислу, дуготрајни преговори Порте и британских финансијера били су добродошли. Тек у септембру, три месеца после питања упућеног из Београда, кнезу је усмено саопштено да би било пожељно сачекати одлуке Порте о овом питању. Но, да не би створили утисак да је аустријска влада у принципу против овог пројекта, из Беча су негативан ефекат учињеног саопштења настојали да компензују начелним пристанком да влада упути опуномоћеника у Беч на разговоре о финансијском аспекту питања, односно обезбеђењу неопходног капитала. ${ }^{91}$ Другим речима, понуда српског кнеза није отворено одбијена, али му је на дипломатски начин стављено до знања да би било пожељно сачекати повољнији тренутак. ${ }^{92}$ Радосављевић се пред кнезом и даље изјашњавао против британског пројекта отворено изјављујући да Аустрија никада неће дозволити британској компанији да гради железницу у Србији и стављајући у изглед споразум са владом у Бечу. ${ }^{93}$ Тек вести о намерама аустријске владе да гради железницу која је на Дунав требало да изађе јужно од Ђердапа, код Оршаве, науштрб интересима Београда и Србије, увериле су српског кнеза у неискреност Радосављевићевих савета и подстакле га да у пролеће 1853. Фонбланку изјави спремност да са британском компанијом преговара о изградњи железнице у Србији. ${ }^{94}$ У том тренутку, била је то само формална изјава о начелној сагласности, јер преговори Порте и британских финансијера, упркос обећавајућем почетку, нису довели до уступања концесије за изградњу трансбалканске железнице и за њену експлоатацију. Још увек је било рано за изградњу прве железнице у Османском царству уз помоћ страног капитала. Тек рат 1853-1855. у савезништву са Великом Британијом и Француском, праћен значајним задуживањем у иностранству услед ратних потреба, довешће до отварања Османског царства за продор страног капитала, посебно за велике инфраструктурне пројекте, какав је била изградња железнице. ${ }^{95}$

Разматрајући значај британских планова о привредном продору у унутрашњост Балкана почетком педесетих година 19. века, могли бисмо истаћи да су се они подударали са до тада најзначајнијим напорима српске владе на плану економског развоја државе. Међутим, упркос томе, посматрајући делатност кнеза

\footnotetext{
${ }^{91}$ W. Rechberger, Ein Beitrag, 30-32.

${ }^{92}$ Исти, Österreichische Eisenbahnpolitik, 350.

${ }^{93}$ Фонбланк Роузу, Београд 1. марта 1853, № 8, FO 195/407. Исти документ у: FO 78/942.

${ }^{94}$ Исти Кларендону, Београд 25. априла 1853, № 4, FO 78/946.

${ }^{95}$ Sevket Pamuk, Foreign Trade, Foreign Capital and the Peripheralization of the Ottoman Empire 1830-1913, рукопис докторске дисертације, University of California, Berkeley 1978; 95-102; G. Rosegger, J. H. Jensen, British Railway Builders along the Lower Danube 1856-1869, The Slavonic and East European Review, Volume XLVI, № 106 (January 1968), London 1968, 106-109; W. Rechberger, Ein Beitrag, 33-43; Y. N. Karkar, нав. дело, 65-66; S. Khairallah, нав. дело, 49-50; М. Самарџић, Железничко питање у спољној политици Србије, 24-30.
} 
Александра и уставобранитеља у вези са британским инфраструктурним пројектима, посебно идејом изградње трансбалканске железнице, намеће се закључак да је бављење овим проблемом било у највећој мери спољнополитички условљено. Док је саобраћајно повезивање са јадранским лукама и отварање српској трговини новог пута ка европским тржиштима, независног од аустријске контроле, у значајној мери кореспондирало са потребама, финансијским могућностима и степеном привредног развоја Србије, изградња железнице несумњиво је превазилазила потребе неразвијеног српског тржишта и заостале, аграрне привреде која је била далеко од развоја који би наметао неопходност обезбеђења бржег транспорта веће количине производа. Међутим, без обзира на доминантно спољнополитичку условљеност, од посебног је значаја чињеница да су, ставом који су заузели у односу на преговоре Порте и британских финансијера о изградњи трансбалканске железнице, кнез Александар и уставобранитељи већ тада поставили основни принцип којег су се држали и будући владари и владе - никакав споразум који би Порта постигла са неким страним друштвом није се могао односити на Србију уколико српски владар и влада не пристану на то. Србија је намеравала да самостално одлучује о овом питању упркос свом вазалном положају. Изградња железнице била је исувише значајна за политички и привредни развој сваке државе да би српска влада дозволила да се о овом питању одлучује мимо знања њених легитимних представника.

\section{Извори и литература:}

Извори:

Архив Србије, Фонд Илије Гарашанина.

Архив Србије, Foreign Office.

Архив Србије, Ministère des Affaires Étrangères, Archives Diplomatiques, Correspondance Commerciale, Belgrade, 1848-1862, Tome 2.

Босна и Херчеговина за везировања Омер-паме Латаса: исправе из бечког државног архива, сабрао Ф. Шишић, Зборник за историју, језик и књижевност српског народа: друго одељење: споменици на туђим језицима: књига XIII, Суботица 1938.

Зборник закона и уредаба у Кнажеству Србији у досадањим зборницима нештампаних а изданих од 2. Фебруара 1835. до 23. Октобра 1875. год., 30, Београд 1877.

Писма Илије Гарашанина Јовану Мариновићу: књига прва: од 29 марта 1848 до 31 дец. 1858, средио Ст. Ловчевић, Београд 1931.

Сборникъ законаิ и уредбаิ, и уредбены указа, изданы' у Княжеству Србскомъ одъ 1-огъ Януара 1847 до кониа Декемвра 1848, IV, Београд 1849.

Сборникъ закона' и уредба', и уредбенны' указа' изданы' у Княжеству Србіи. (Одъ потетка 1851. до кониа 1852. године.), VI, Београд 1853.

Sundhaussen, H., Historische Statistik Serbiens 1834-1914: mit europäischen Vergleichsdaten, München 1989. 
Литература:

Антић, Ч., Велика Британија, Србија и Кримски рат (1853-1856): неутралност као независност, Београд 2004.

Арнаутовић, Д., Историја Српских железница 1850-1918, Београд 1934.

Арнаутовић, Д., Histoire des chemins de fer Yougoslaves 1825-1937, Paris 1937.

Bailey, F. E., The Economics of British Foreign Policy 1825-1850, The Journal of Modern History, Volume XII, December 1940, Number 4, 449-466.

Berend, I. T., Ránki G., Evropska periferija i industrijalizacija 1780-1914, Zagreb 1996.

Берић, Д., Илија Гарашанин и устанак у Херцеговини 1852-1854, В. Стојанчевић (ур.), Илија Гараманин (1812-1874): зборник радова са међународног научног скупа одржаног 9. и 10. деиембра 1987. поводом 175. годишњиие рођења, Београд 1991.

Влајинац, М. З., Згон или кулучење ван места становања од средњег века до наших дана. Прилог историји народног живота и рада, Српски етнографски зборник, СКА, књига XLIX, друго одељење Животи и обичаји народни, књига 21, Београд 1932.

Вучо, Н., Развој индустрије у Србији у ХІХ веку, Београд 1981.

Vučo, Nikola, Železnički saobraćaj kao faktor privrednog razvoja Srbije u XIX. veku, Acta historico oeconomica Iugoslaviae, $\mathrm{V}$ (1978).

Гелнер, Е., Наиије и национализам, Нови Сад 1997.

Грујић, М. - Бундало, З., Железнице Србије, Београд 2004.

Grunwald, K., Türkenhirsch: A Study of Baron Maurice de Hirsch, Entrepreneur and Philanthropist, Jerusalem 1966.

Дашић, М., Додири и везе ирногорских брдских племена и Србије у доба владавине уставобранитељског режима, В. Стојанчевић (ур.), Илија Гараманин (1812-1874): зборник радова са међународног научног скупа одржаног 9. и 10. децембра 1987. поводом 175. годишњиие рођења, Београд 1991.

Ђетва,ј Д. П., Развој међународног уговорног капаиитета Србије у ХІХ веку, Суботица 1939.

Ђорђевић, Д., Србија и српско друштво 1880-тих година, Историјски часопис, XXIX-XXX (1983).

Ђурић, Ђ., Вук Маринковић, биографија и научни рад утемељивача физике као модерне науке у Србији, Нови Сад 2007.

Ивковић, Т. Ђ., Споменица двадесетпетогодишњице српских државних железница: од 3. Септембра 1884. до 3. Септембра 1909. год, Београд 1909.

Јовановић, С., Уставобранитељи и њихова влада, Београд 1990.

Juzbašić, Dž., Izgradnja željeznica u Bosni i Hercegovini u svjetlu austrougarske politike od okupacije do kraja Kállayeve ere, Sarajevo 1974.

Karkar, Y. N., Railway Development in the Ottoman Empire 1856-1914, New York 1972.

Khairallah, S., Railways in the Middle East 1856-1948: Political and Economic Background, Beirut 1991.

Крестић, В., Историја српске штампе у Угарској 1791-1914, Нови Сад 1980.

Lampe, J. R., Financial Structure and the Economic Development of Serbia 1878-1912, рукопис докторске дисертације, University of Wisconsin, 1971.

Lanier, A., Die Geschichte des Bank- und Handelshauses Sina, Frankfurt/M. - Berlin - Bern - New York - Paris - Wien 1998.

Љушић, Р., Кнежевина Србија (1830-1839), Београд 1986. 
Љушић, Р., Књига о Начертанију: национални и државни програм Кнежевине Србије (1844), Београд 1993.

Majdan, J., A magyar-szerb vasúti kapcsolatok kiépülése, y: 3. Ђере (ур.), Српско-мађарски односи кроз историју: зборник радова са међународног научног скупа одржаног 15. јуна 2007. године у Новом Саду, Нови Сад 2007.

Мекензи, Д., Илија Гарашанин: државник и дипломата, Београд 1987.

Миленковић, В., Економска историја Београда до светскога рата, Београд 1932.

Миленковић, П., Историја грађења железница и железничка политика код нас (1850-1935), Београд 1936.

Милић, Д., Страни капитал у рударству Србије до 1918, Београд 1970.

Милић, Д., Илија Гарашанин и привреда Србије, В. Стојанчевић (ур.), Илија Гарашанин (1812-1874): зборник радова са међународног научног скупа одржаног 9. и 10. децембра 1987. поводом 175. годишњиие рођења, Београд 1991.

Милић, Д., Die Pläne zum ausbau der Eisenbahn in Serbien in der Mitte des 19. Jahrhunderts, R. G. Plaschka (yp.), Eisenbahnbau und Kapitalinteressen in der Beziehungen der Österreichischen mit den Südslawischen Ländern, Wien 1993

Милошевић, С. Ђ., Спољна трговина Србије од 1843-1875 године, Београд 1902.

Митровић, Ј. Д., Рад Матије Бана у Дубровнику 1848-1850. по налогу владе Србије и Илије Гарашанина, В. Стојанчевић (ур.), Илија Гарашанин (1812-1874): зборник радова са међународног научног скупа одржаног 9. и 10. децембра 1987. поводом 175. годишњице рођења, Београд 1991, 361-368.

Мрђеновић, Ђ., Гвоздени пут Србије, Београд 1974.

Николић, Ј. С., Историја железница Србије, Војводине, Црне Горе и Косова, Београд 1980.

Павићевић, Б., Стварање ирногорске државе, Београд 1955.

Паларе, М., Балканске привреде око 1800 - 1914: еволуиија без развоја, Београд 2010.

Pamuk, S., Foreign Trade, Foreign Capital and the Peripheralization of the Ottoman Empire 1830 1913, рукопис докторске дисертације, University of California, Berkeley 1978.

Пауновић-Штерменски, Ј., Урквартово виђење међународног положаја Србије, Београд 2007.

Петровић, С., Сто година пољопривредних школа у Србији (1853-1953), Београд 1956.

Polanji, K., Velika transformacija: politička i ekonomska ishodišta našeg vremena, Beograd 2003.

Поповић, В., Политика Франиуске и Аустрије на Балкану у време Наполеона III, Београд 1925.

Поповић, В., Аграрно питање у Босни и турски нереди за време реформног режима АбдулМеиида (1839-1861), Београд 1949.

Поповић, Р., Аврам Петронијевић, рукопис докторске дисертације, Београд 2009.

Raičević, J., Železnice u Srbiji 1884-1958, Privredna hronika, VI (1959), 3-107.

Растовић, А., Велика Британија и Србија (1878-1889), Београд 2000.

Rechberger, W., Zur Geschichte der Orientbahnen: Ein Beitrag zur österreichisch-ungarischen Eisenbahnpolitik auf dem Balkan in den Jahren von 1852-1888, рукопис докторске дисертације, Wien 1958.

Rechberger, W., Zur Geschichte der Orientbahnen: Österreichische Eisenbahnpolitik auf dem Balkan (=Österreichische Eisenbahnpolitik), Österreichische Osthefte, 5 (1960).

Rosegger, G., Jensen, J. H., Transylvanian Railways and Access to the Lower Danube 1856-1914, East European Quarterly, XXIX, 4 (January 1996).

Rosegger, G., Jensen, J. H., British Railway Builders along the Lower Danube 1856-1869, The Slavonic and East European Review, Volume XLVI, Number 106 (January 1968),

Самарџић, М., Посета барона Хердера Србији и први план за изградњу железнице, Истраживања, 18, Нови Сад 2007. 
Самарџић, М., Железничко питање у спољној политици Србије 1878-1888, рукопис докторске дисертације, Нови Сад 2007.

Самарџић, М., Roads to Europe: Serbian Politics and the Railway Issue 1878-1881, Pisa 2010.

Симић, В., Из скорашње прошлости рударства у Србији, Београд 1960.

Страњаковић, Д., Влада уставобранитеља 1842-1853: унутрашња и спољашња политика, Београд 1932.

Чалић, М-Ж., Соиијална историја Србије 1815-1941: успорени напредак у индустријализаиији, Београд 2004. 


\title{
FACING THE MODERNIZATION CHALLENGE - BRITISH INFRASTRUCTURAL PROJECTS ON THE BALKANS 1851 - 1852 AND SERBIA
}

\begin{abstract}
Summary
British plans for economic infiltration into the interior of the Balkans in the early fifties of the nineteenth century coincided with the then major efforts of the Serbian government in the field of economic development of the country, and desires for liberation of the Serbian trade from the Austrian monopoly. Observing the activities of Prince Alexander and the Constitution defenders related to the British infrastructure projects, especially to the idea of Trans-Balkan railway construction, the conclusion has been made that dealing with this problem was conditioned by the dominant foreign policy. While the traffic connection with the Adriatic ports and the opening of the Serbian trade towards the new route to European markets, which was independent of the Austrian control, mostly corresponded with the needs, financial capabilities and a level of economic development of Serbia, the construction of the railway undoubtedly exceeded the needs of the undeveloped Serbian market and the backward agrarian economy that was far from development which would impose the necessity to provide faster transport of the large quantities of products. However, regardless of the foreign policy requirements, a particular importance was given to the fact that the position taken in relation to negotiations between Porta and British financiers to build the Trans-Balkan railway set up the basic principle of the Prince Alexander and the defenders of the Constitution, which was the principle of the future rulers and governments as well - any agreement made between Porta and a foreign company could not apply to Serbia if the Serbian ruler and the government did not agree to it. Serbia intended to independently decide on this issue despite of its vassal status. Construction of the railway was too important for political and economic development of each country, and therefore the Serbian government did not allow deciding on this matter without the knowledge of their legitimate representatives.
\end{abstract}

Keywords: modernization, road infrastructure, Trans-Balkan railway, Great Britain, Serbia, Ottoman Empire, Defenders of the Constitution, the Eastern question, 1851-1852 